\title{
Prestige, Parallel or Predatory - \\ Pricing Strategies amongst Taiwanese Universities
}

\author{
Hsuan-fu Ho \\ Assistant Professor \\ Graduate Institute of Educational Administration and Policy Development \\ National Chiayi University, Taiwan \\ 85 Wenlong Minshong, Chiayi County 62103, Taiwan \\ E-mail: hfho@mail.ncyu.edu.tw \\ Fang-Ying Wang \\ Department of Education, National Chiayi University, Taiwan \\ 85 Wenlong Minshong, Chiayi County 62103, Taiwan \\ E-mail: garfield9_17@hotmail.com
}

Received: May 6, 2011 Accepted: June 17, 2011 doi:10.5539/ijms.v3n3p67

\begin{abstract}
Many countries throughout the world are actively striving to expand higher education, but the public funding available for higher education is not commensurate with the rapidly increasing number of colleges and universities, bringing about serious financial deficits and compromises in quality at many schools. In such an environment, tuition is one of the most important sources of funding, such that the financial health of many schools largely depends on the success of their tuition pricing strategy. This research is thus aimed to determine how much tuition the potential students were willing to pay to attend different schools, and to calculate the optimal rate of tuition each school should charge with respect to prestige pricing, parallel pricing, and predatory pricing. Most administrative personnel at academic institutions, when formulating tuition rates, do no more research than checking to see what other schools are charging, without giving much consideration to differences in quality. The results of this research can be used as a reference by the case schools it examines to select a suitable pricing strategy in a rapidly shrinking market. More importantly, it is hoped that other universities will be able to make use of this simple, quality-based pricing methodology developed in this research.
\end{abstract}

Keywords: School marketing, School finance, Pricing, Tuition, Higher education

\section{Motivation and purpose of the research}

Many countries throughout the world are actively striving to expand higher education, both in order to enhance national competiveness and also to satisfy the popular demand for universal education. Yet, the public funding available for higher education is not commensurate with the rapidly increasing number of colleges and universities, bringing about serious financial deficits and compromises in quality at many schools. As a result, finding and making the best use of non-governmental sources of funding has become one of the greatest challenges facing today's institutions of higher education. In such an environment, tuition is one of the most important sources of funding, such that the financial health of many schools largely depends on the success of their tuition pricing strategy.

A large number of factors need to be considered when investigating the suitability of a particular pricing strategy. In order to maintain market competitiveness, in addition to the school's overhead, it's also necessary to consider what sort of financial burden students are willing and able to bear, as well the tuition rates being charged by similar schools. Moreover, since education has a higher degree of social responsibility in comparison to other industries, when formulating tuition policies, schools need to pay relatively more attention to government regulations and political factors, as well as public opinion (Gray 1991; Kotler and Fox 1995; McClatchey 1998). 
Despite its importance, little research has been conducted on tuition rates in higher education, and this lack is especially acute in Taiwan. Previously in Taiwan, the government was the main source of funding for universities. However, following the rapid increase in the number of universities, the government is no longer able to do so. Although universities in Taiwan now give great importance to tuition pricing, little research has been carried out which would be of assistance in selecting the best pricing strategy and formulating optimal tuition rates. In this study we demonstrate how this could be done by continuing education M.A. programs in education at four universities located in southern Taiwan.

Because working students in continuing education programs mostly study on a part-time basis outside of work hours, in comparison to other types of students, they are more localized in their choice of school. This makes such programs highly suitable for a study of tuition pricing strategies in a particular region. For this study we chose the faculty members of primary and secondary schools in southern Taiwan as the target population, since they constitute the main source of potential students for continuing education M.A. programs. The goals of the research were as follows:

1) Determine how much tuition the potential students were willing to pay to attend different schools.

2) Determine the influence such factors as gender, seniority, and the grade one is teaching have on the amount of tuition the potential students were willing to pay.

3) Determine the factors which have the greatest influence on a student's evaluation of a school's quality, as well as the relative weighting of these factors.

4) Clarify the student-perceived quality of each program and use this as the basis for formulating a competitive pricing structure.

5) From the perspective of market competition, calculate the optimal rate of tuition each school should charge with respect to prestige pricing, parallel pricing, and predatory pricing.

\section{Literature review}

In the past, a university education was mainly limited to the higher echelons of society, a situation which kept student numbers low and made it unnecessary to charge tuition and other fees. In recent times, however, higher education has gradually been transformed from an elite system into a mass system and, finally, into a universal system (Trow, 1974). At present, however, most national governments can no longer afford to provide the bulk of the operating expenses of this greatly increased number of universities. In order to maintain the quality of education, it has thus become necessary for universities to find alternative sources of funding, one result of which is that tuition pricing has gradually become a major issue for most institutions of higher education (Edirisooriya, 2009).

The research of Bowie, Cherry, and Wooding (2005) indicates that tuition rates and school-based scholarships have a clear influence on a student's willingness to attend a particular school. Similarly, Padlee and Kamaruddin (2010) found that cost factors such as tuition fees and cost of living influence a potential student's choice of school. According to Ohern's (2010) research, every $\$ 79$ increase in tuition and fees results in the loss of one student. Although most of the related studies found a significant correlation between a school's tuition structure and its ability to recruit students, Vasigh and Hamzaee (2004) found no such correlation. Interestingly, Dotterweich and Baryla (2005) found that although the tuition rates of public universities had no marked influence on enrollment numbers, they did make a clear difference at private universities.

Lovelock, Vandermerwe, and Lewis (1999) emphasized that in formulating pricing strategies commercial organizations need to pay special attention to the three Cs of pricing: costs, customers, and competitors. In a related study, Lilien and Rangaswamy (2004) identify three distinct types of pricing: cost oriented pricing, customer demand oriented pricing, and competition oriented pricing. They also point out that in normal circumstances a commercial organization's revenues must be higher than its overhead, and that the organization's overhead is the lowest price at which it can feasibly provide a good or service. They also stressed that the formulation of an optimal pricing structure (the one which results in the largest sales volume and revenue) requires an understanding of the relationship between pricing and a customer's willingness to buy. Finally, in a highly competitive environment, pricing has a major influence on sales volume, making it very important to have a detailed knowledge of the pricing of one's competitors when formulating one's own pricing strategy.

While universities are non-profit organizations, they are similar to commercial enterprises in that they have to compete with each other for students, donations, and faculty. When competition is intense, schools need to enhance their competitiveness by being familiar with the marketing strategies commonly employed by commercial enterprises (Massy, 2004). Nonetheless, it is clearly the case that not all such marketing strategies 
are suitable for all schools, so obtaining the best results requires giving due consideration to the school's characteristics and making whatever adaptations which may be necessary (Kim and Lee, 2006).

In fact, there are a number of key differences between the pricing strategies employed by universities and those of the average commercial organization. An ordinary enterprise mainly relies on the profits derived from the sale of its products or services to cover its operating expenses, with the aim being to gain the highest possible profit; for this reason its pricing structure is usually based on a multiple of its operating expenses. By contrast, an educational organization typically depends on donations and government funding to cover at least some of its operating costs. Moreover, setting tuition rates too high can have a deleterious effect on a school by giving rise to negative reactions from government and society at large.

Looney (2003) emphasized that the pricing strategies of most commercial organizations is primarily geared towards obtaining short-term profits, but schools need to give more consideration to long-term plans. The main reason for this is that, unlike commercial enterprises, schools can't make frequent changes to their pricing structures. Students pay tuition only once or twice a year, and in between they are unaffected by any changes in pricing, largely eliminating the incentive for a school to rapidly adjust its pricing in response to market changes. Parrott (2008) and Bishop and Colwell (1991) pointed out that the main goal of a school's pricing strategy should not be maximizing its income, but rather attracting the best students, for which reason some schools offer tuition discounts and financial aid to promising students. Moreover, an enterprise seeks to maximize its profits by formulating the customer-oriented pricing strategy which is able to attract the largest number of customers willing to pay the highest acceptable price for its goods or services. In the case of a school, however, such a pricing strategy is not suitable, since the number of customers/students a school can serve at a given time is relatively limited (Ho, 2010).

Still, in a highly competitive environment, adopting a competitive pricing strategy is essential to a school's survival. For an ordinary enterprise, there are three options to choose from when deciding on a pricing strategy: prestige pricing; parallel pricing, and predatory pricing (Smith and Quelch, 1993; Sandhusen, 2000). These three pricing strategies can also be adopted by schools. If a given school is of a higher quality than its competitors, or if it's competing for a niche market, it can adopt prestige pricing (charging tuition rates higher than those of its competitors) as a way of increasing its revenues and enhancing the perceived quality of its product amongst consumers (Akhter, 2009; McMillen, Singell, and Waddell, 2007). But when competition is not very intense a harmonious relationship between schools is most beneficial, and this is the appropriate situation in which to adopt parallel pricing, the most commonly seen pricing strategy in education (Mass, 2004; Moore, 1995). Predatory pricing is setting the cost of one's goods or services below those of one's competitors in an effort to attract the maximum number of customers, and is sometimes used by schools to increase revenues by increasing student enrollment; in some cases the intention is to put competitors out of business and then make significant increases in tuition fees (Anderson, Wouters, and Rossum, 2010).

There exists an interactive relationship between pricing and quality. Normally, a customer will pay no more for a product than what he perceives to be its actual value, and this needs to be kept in mind when formulating a pricing strategy (Lovelock and Wirtz, 2007). Yet, Jackson and Narasimhan (2010) warn that if an enterprise is unable to convince potential customers of the quality of its goods or services, a high quality-high price strategy is likely to fail. In such a case, the organization would do well to make a suitable price reduction in order to encourage more customers to buy the product and become familiar with its quality.

The quality of a school naturally influences the amount tuition its potential students are willing to pay. Moreover, students are normally willing to pay more tuition to attend what they perceive to be a better school, in the belief that they will realize greater benefits by attending such a school. In turn, tuition rates can have an influence on a student's perceived quality of a school. Due to the existence in the education industry of what is known as "information asymmetry," many potential students take tuition as the main benchmark for evaluating a school's quality, laboring under the mistaken belief that the higher the tuition, the better the quality (McMillen, Singell, and Waddell, 2007). Also, because a school can enroll only a limited number of students at any given time, many schools prefer to use higher tuition rates to attract better students, rather than using lower tuition rates to attract a larger number of students.

Actually, this type of value-based or quality-based pricing is already being used by many schools (Ho, 2010). For example, most colleges and universities in the US take the tuition rates of elite schools as a benchmark for setting their own tuition rates (Mass, 2004). The amount of tuition a school can charge hinges on the strength of its potential students' desire to attend that school. Thus, in setting its tuition rates, a school needs to have a clear understanding of the main factors students take into account when evaluating a school's quality, as well as how it 
measures up on these factors in comparison with its competitors. In this way, a school can formulate a tuition strategy and rate which is commensurate with what it has to offer potential students.

Bowie, Cherry, and Wooding (2005) found that when university students select a graduate school they give most importance to five factors: geographic location; type of program; class scheduling; cost of tuition; and academic reputation. Padlee and Kamaruddin (2010) found that the six factors students planning to study abroad give most importance to when selecting a school are quality of the learning environment; influencers; customer focus; cost; facilities; socialization; and location. Ho and Hung (2008) found that the factors Taiwanese university students give most importance to when selecting a graduate school are school location; nearby facilities; campus aesthetics; teacher quality; curriculum design; research reputation; academic reputation; alumni reputation; cost; availability of scholarships; topics on the entrance exam; success rate on the entrance exam; and graduation requirements. These are the factors a school needs to assess in its endeavor to adopt the optimal pricing strategy and tuition rates.

In summary, this study was designed to first determine the factors potential continuing education students in Taiwan give most importance to when selecting a university extension M.A. program in education. In turn, four such programs were rated with respect to each of these factors. Finally, taking into account the intense competition for students in Taiwan, we calculated the optimal tuition levels for each school for each of the three pricing strategies.

\section{Research methodology}

This research focuses on the pricing strategies employed by four continuing education M.A. programs in education in Taiwan. The procedures, tools, and sample population are described below.

\subsection{Research procedure}

We began by creating and administering a questionnaire to determine the factors the participants give most importance to when selecting a university program, and then calculated the relative weight of each factor. We then used another questionnaire to determine the amount of tuition they would be willing to pay to attend the school with the highest quality and the school with the lowest quality. Next, we calculated the corresponding price differential for every one-level increase or decrease on each of the factors. Thereafter, we used another questionnaire to calculate the average score of each school on each factor, as well as the actual tuition each school was currently charging for each factor. We then used this information to calculate the optimal tuition rate for each school with respect to prestige pricing, parallel pricing, and predatory pricing. Finally, we used the information thus obtained to make suggestions as to which pricing strategy each of the four schools should adopt, and how much tuition they should charge. A flow chart of the research methodology is presented as figure 1.

We mainly used the analytic hierarch process (AHP) to determine the weighting of each factor. AHP is a method for making strategic decisions which incorporates human judgments and uses a hierarchy to make clear the subordinate relationships between each of the factors being considered. A pair-wise comparison was used to create a questionnaire, and finally a positive reciprocal matrix was used to calculate the weighting (Saaty, 1990; Saaty and Vargas, 1994). The factor hierarchy in this study was presented as figure 2.

\subsection{Research tools}

The primary research tool used in this study was the self-created "Survey of the Pricing Strategies of Continuing Education M.A. Programs in Taiwan," which consists of four parts. Part one is designed to obtain such background information about the participants as gender, the characteristics of the school they teach at, the grades they teach, professional title, and teaching seniority. Part Two is divided into seven topics according to the pair-wise factor comparison of the AHP, and was used to calculate the relative weight of the eight key factors: curriculum design, teacher quality, school location, research facilities, admission criteria, graduation requirements; relevance to one's current work; and career advancement. Part Three uses a five-point Likert scale for rating each school on each of these eight factors. Part Four focuses on pricing, and is designed to determine the amount of tuition the participants would be willing to pay to attend a school perceived to be of very low quality, and one perceived to be of very high quality.

\subsection{Research subjects and sampling}

In recent years universities in Taiwan have begun to give much importance to pricing strategies, yet the tuition of bachelors degree and daytime graduate programs at public universities is still strictly controlled by the government. Only the tuition rates of continuing education programs are completely decided by the universities themselves, and such programs have become a major source of self-generated revenue for many schools. For this reason we selected as the subject of this research four universities (designated by the pseudonyms UA, UB, UC, 
and UD) located in central and southern Taiwan with continuing education M.A. programs in education designed for working adults. Because most of the potential recruits for such programs are faculty members of primary and secondary schools in the same area, we selected them as our sample population.

Sample size has a direct influence on research results. If the sample size is too small, it will be difficult to reach the significance level, but the effect size will be higher. By contrast, if the sample size is too large, although it will be easy to reach the significance level, the effect size will be lower, thereby lowering the reliability of the results. Thus it is important to determine the most suitable sample size. In this research we utilized the sample size calculation table developed by Cohen (1992). After checking the table we discovered that when carrying out ANOVA with the five possible choices as the basis of calculation, in order to reach a medium effect size $\left(\eta^{2}=\right.$ 0.25 ) and a medium statistical power $(\alpha=0.5)$, the sample size would need to be around 195. Accordingly, assuming a $65 \%$ retrieval rate, we sent out 300 questionnaires. We used random sampling to select 30 schools in southern Taiwan, and sent the questionnaire to ten teachers at each of these schools. A total of 209 valid questionnaires were returned, making a retrieval rate of $70 \%$.

\section{Results}

The results indicate that the participants were willing to pay an average of US\$977 per semester to attend the school perceived to have the best quality, and US\$345 to attend the school perceived to have the lowest quality, an average of US\$661. Yet, the actual total fees (tuition plus per-credit fees) charged per semester by the continuing education programs examined in this study were US\$913 for UA, US $\$ 1,666$ for UB, US\$1,692 for UC, US\$1,283 for UD. Thus it is clear that of the four programs, only the cost of UA was below what the participants would be willing to pay to attend a high-quality program.

It was also found that the characteristics of the participant's school, their position, and their seniority had no influence on the amount of tuition they would be willing to pay. The factors that did have a marked influence were gender and the grade they teach. We also found that the male participants were willing to pay more than the females, but the amount females were willing to pay was much more influenced by their perceptions of a school's quality. Moreover, high school teachers were willing to pay more than the other teachers, and the amount they were willing to pay was much more influenced by their perception of a school's quality (see table 1; table 2)

Next, in order to calculate the weighting of each factor, we used the paired factor comparison of the AHP to come up with a group of questionnaire items; a positive reciprocal matrix was used to calculate the weighting of each factor (see table 3 ).

Using the data in the table above, we calculated the relative weighting of each factor with respect to its importance for attaining the primary goal. The weights were calculated by multiplying the score of each factor by the score of its subordinate aspect and the score of its subordinate dimension. The results are displayed in figure 3 .

As can be seen in figure 3, the participants gave most importance to the extent to which what they learn in a continuing education program will be of practical benefit to their teaching and administrative work. Next most important was the quality of instruction at the prospective university, followed by graduation requirements and how much completing such a course of study would increase their chances of getting a promotion. The graph also shows that the participants gave the least importance to research facilities, curriculum design, school location, and admission criteria.

The next part of the research was to have the participants rate each of the four schools on each factor using a scale of $1-5$, and then calculate the averages. We then combined the relative weights for each factor and added together the price differential between the school with the highest score and the school with the lowest score. This made it possible to calculate how much more tuition a school can charge when its quality rating increases one level on a given factor, and, conversely, how much less it should charge when its rating decreases one level on a given factor (see table 4). The formula is as follows:

$$
\mathrm{WP}=\mathrm{W} \times \mathrm{Pd} \div(5-1)
$$

WP: The weighted price differential between each rating level

$\mathrm{W}$ : The weighting for each factor

Pd: The price differential between the highest and lowest quality

In a competitive market, the first step in formulating a pricing strategy is to give due consideration to what one's main competitors are charging for the same goods or services. In the case of tuition pricing, it's necessary to 
know the average tuition being charged by one's competitors, but, due to differences in the quality of schools and the differing importance prospective students give to different factors, this can't be done directly by making a simple comparison of tuition rates. By collating the data obtained through the questionnaire, we calculated the average scores on each factor for each of the four schools, as shown in table 5.

After calculating the difference on a given factor between a given school and its competitors, we multiplied this figure by the weighted price differential, and then added to the figure thus obtained the actual tuition fees being charged by the university. The final result was the comparative market pricing of each university. The formula is as follows:

$\mathrm{Q} \mathrm{i}=$ The quality differential

$\mathrm{Wi}=$ The weighting for each factor

$\mathrm{P} 1=$ The tuition pricing of one's competitors after factoring in differences in quality

P2 = The actual tuition pricing of one's competitors

The above formula was used to calculate the tuition rates in U.S. dollars, and the results (see table 6) were then been used to determine the optimal pricing for each school with respect to prestige, parallel, and predatory pricing. Prestige pricing requires setting the cost of one's product above that of the highest price being charged by one's competitors for the same product, while predatory pricing requires the reverse. Parallel pricing is setting ones prices on par with one's competitors.

\section{Conclusion}

In a competitive marketplace a university needs to adopt a competitive pricing strategy, one which gives due consideration to the quality and pricing of its main competitors. We selected as the targets of this study four universities in central and southern Taiwan which have continuing education programs in education, and the primary and secondary school teachers in the same region who are the main recruitment pool for such programs. Based on the data obtained from the questionnaire, we calculated the optimal pricing for each university with respect to each of the three types of pricing strategies.

Once the adjustments were applied, it became clear that the pricing of UA was significantly lower than that of its competitors. If UA were to adopt a prestige pricing strategy it would need to charge more than US $\$ 1,765$ per semester; for parallel pricing its optimal tuition would be around US\$1,576; and for predatory pricing it would have to charge less than US\$1,316. Because UA was rated quite high on each of the factors examined in this study, it may raise its tuition with whatever pricing strategy it uses.

If UB were to adopt a prestige pricing strategy it would need to charge more than US $\$ 1,785$ per semester; for parallel pricing its optimal tuition would be around US $\$ 1,351$; and for predatory pricing it would have to charge less than US\$933. The present pricing of UB is well above the market average, but because it was rated higher on most factors, it could easily charge more tuition to increase its revenues and enhance its image as a high-quality school. Also, the pricing of UB would be more attractive to female teachers and high school teachers; because the findings indicate that these two groups are more sensitive to the price-quality relationship than are other teachers.

If UC were to adopt a prestige pricing strategy it would need to charge more than US $\$ 1,573$ per semester; for parallel pricing its optimal tuition would be around US $\$ 1,219$; and for predatory pricing it would have to charge less than US\$840. Although UC currently charges considerably more for tuition than the other three universities, the only factor in which it was rated higher than all the others was graduation requirements. Since it was rated much lower than the others on all the other factors it's unlikely that it would succeed by adopting a prestige pricing strategy.

If a school charges excessive tuition, it will only be able to attract students who are looking for the easiest way to get a degree, and its overall quality will suffer in the long run. UC is currently still able to use its high-tuition, low-quality strategy to recruit wealthy students who are more interested in a degree than in a quality education. Yet, because the number of potential graduate students in Taiwan is rapidly shrinking, if UC doesn't quickly take measures to improve its quality, it may soon find itself without students.

If UD were to adopt a prestige pricing strategy it would need to charge more than US\$1,731 per semester; for parallel pricing its optimal tuition would be around US $\$ 1,408$; and for predatory pricing it would have to charge less than US $\$ 880$. Of the four schools in this study, the tuition charged by UD was closest to the average market rate, but its ratings on each of the factors were somewhat below average, so it would be ill-advised to adopt a 
prestige pricing strategy. In addition, UD would do well to avoid initiating a price war, since a school with below-average quality is unlikely to derive any benefit by doing so. Thus it would be in UD's best interests to adopt a parallel pricing strategy.

Few administrative personnel at academic institutions have any knowledge of pricing, and it's quite difficult to find simple and clear guidance in the subject. In such a situation, when formulating tuition rates, most universities do no more research than checking to see what other schools are charging, without giving much consideration to differences in quality. The results of this research can be used as a reference by the four schools it examines to select a suitable pricing strategy in a rapidly shrinking market. More importantly, it is hoped that other universities will be able to make use of this simple, quality-based pricing methodology.

\section{References}

Akhter, S. H. (2009). Niches at the edges: Price-value tradeoff, consumer behavior, and marketing strategy. Journal of Product and Brand Management, 18(2), 136-142. doi:10.1108/10610420910949031, http://dx.doi.org/10.1108/10610420910949031.

Anderson, J. C., Wouters, M., \& Rossum, W. V. (2010). Why the highest price isn't the best price. MIT Sloan Management Review, 51(2), 69-76.

Bishop, P. C., \& Colwell, P. F. (1991). Price discrimination and the financial aid process. Illinois Business Review, 48(2), 3-8.

Bowie, S. L., Cherry, D. J., \& Wooding, L. H. (2005). African American MSW students: Personal influences on social work careers and factors in graduate school selection. Social Work Education, 24(2), 169-184. doi:10.1007/BF01228161, http://dx.doi.org/10.1007/BF01228161.

Cohen, J. (1992). A power primer. Psychological Bulletin, 112(1), 155-159. doi:10.1037//0033-2909.112.155, http://dx.doi.org/10.1037//0033-2909.112.155.

Dotterweich, D., \& Baryla, E. A. (2005). Non-resident tuition and enrollment in higher education: Implications for tuition pricing. Education Economics, 13(4), 375-385. doi:10.1080/09645290500251631, http://dx.doi.org/10.1080/09645290500251631.

Edirisooriya, G. (2009). A market analysis of the latter half of the nineteenth-century American higher education sector. History of Education, 38(1), 115-132. doi:10.1080/00467600701585666, http://dx.doi.org/10.1080/00467600701585666.

Gray, L. (1991). Marketing education. Bristol. PA: Open University Press.

Ho, H., \& Hung, C. (2008). Marketing mix formulation for higher education: An integrated analysis employing analytic hierarchy process, cluster analysis and correspondence analysis. International Journal of Educational Management, $\quad 22(4), \quad 328-340 . \quad$ doi:10.1108/09513540810875662, http://dx.doi.org/10.1108/09513540810875662.

Ho, H. (2010). Strategic management for school marketing [in Chinese]. Taipei: Wu-Nan Culture Enterprise.

Jackson, E. C., \& Narasimhan, R. (2010). A dynamic pricing game investigating the interaction of price and quality on sales response. Journal of Business \& Economics Research, 8(9), 37-52.

Kim, S., \& Lee, J. (2006). Changing facets of Korean higher education: Market competition and the role of the state. Higher Education, 52(3), 557-587.doi:10.1007/s10734-00501044-0, http://dx.doi.org/10.1007/s10734-00501044-0.

Kotler, P., \& Fox, K. F. A. (1995). Strategic marketing for educational institutions (second edition). Upper Saddle River, NJ: Prentice-Hall.

Lilien, G. L., \& Rangaswamy, A. (2004). Marketing engineering: Computer-assisted marketing analysis and planning (revised second edition). Victoria, BC, Canada: Trafford.

Looney, S. D. (2003). Navigating the rough road to effective pricing. Independent School, 63(1), 68-75.

Lovelock, C., \& Wirtz, J. (2007). Services marketing: People, technology, strategy (sixth edition). Upper Saddle River, NJ: Pearson Prentice Hall.

Lovelock, C., Vandermerwe, S., \& Lewis, B. (1999). Services marketing: A European perspective. Harlow, Great Britain: Prentice Hall Europe.

Massy, W. F. (2004). Markets in higher education: Do they promote internal efficiency? In P. Teixeira, B. Jongbloed, D. D. Dill \& A. Amaral (Eds.), Markets in higher education: Rhetoric or reality (pp. 13-35). The 
Netherlands: Kluwer Academic Publishers.

McClatchey, C. A. (1998). A multi-criteria model for optimizing university tuition structure. Journal of Applied Business Research, 14(2), 117-126.

McMillen, D. P., Singell, L. D., \& Waddell, G. R. (2007). Spatial competition and the price of college. Economic Inquiry, 45(4), 817-833.

Moore, S. T. (1995). Pricing: A normative strategy in the delivery of human services. Social Work, 40(4), 473-81.

Ohern, S. (2010). The impact of tuition pricing changes on the balance of enrollment among Christian religious colleges. Unpublished doctoral dissertation, Prescott Valley, Arizona: Northcentral University.

Padlee, S. F., \& Kamaruddin, A. R. (2010). International students' choice behavior for higher education at Malaysian private universities. International Journal of Marketing Studies, 2(2), 202-211.

Parrott, S. A. (2008). Tuition discounting to optimize enrollment and revenue. Tertiary Education and Management, 14(3), 261-268. doi:10.1080/13583880802246218, http://dx.doi.org/10.1080/13583880802246218.

Saaty, T. L., \& Vargas, L. G. (1994). Decision making in economic, political, social and technological environments with the analytic hierarchy process. Pittsburgh: RWS publications.

Saaty, T. L. (1990). Decision making for leaders: The analytic hierarchy process for decisions in a complex world. Pittsburgh: RWS Publications.

Sandhusen, R. L. (2000). Marketing (third edition). Hauppauge, NY: Barron's Educational Series.

Smith, N. C., \& Quelch, J. A. (1993). Ethics in marketing. Boston: Irwin.

Trow, M. (1974). Problems in the transition from elite to mass higher education. In Policies for higher education (pp. 55-101) [general report on the conference on future structures of post-secondary education]. Paris: Organization for Economic Co-operation and Development.

Vasigh, B., \& Hamzaee, R. G. (2004). Testing sensitivity of student enrollment with respect to tuition at an institution of higher education. International advances in Economic Research, 10(2), 133-149. doi:10.1007/Bf02295676, http://dx.doi.org/10.1007/Bf02295676.

Table 1 . T test of average cost and cost differentials by gender

\begin{tabular}{|c|c|c|c|c|c|c|}
\hline Item & Group & $\mathrm{N}$ & $\mathrm{M}$ & $\mathrm{SD}$ & $\mathrm{t}$ & $\mathrm{P}$ \\
\hline \multirow{2}{*}{ Average cost } & 1.Male & 88 & 703.60 & 298.96 & \multirow{2}{*}{1.98} & .010 \\
\cline { 2 - 7 } & 2.Female & 120 & 627.08 & 238.16 & & \multirow{2}{*}{. .684} \\
\hline \multirow{2}{*}{$\begin{array}{c}\text { Quality-generated } \\
\text { cost differential }\end{array}$} & 1.Male & 88 & 607.95 & 403.56 & .008 \\
\cline { 2 - 7 } & 2.Female & 120 & 643.06 & 305.79 & & \\
\hline
\end{tabular}

Table 2. ANOVA of costs by level of education

\begin{tabular}{|c|c|c|c|c|c|c|c|c|}
\hline & \multirow{2}{*}{ Group } & \multirow{2}{*}{$\mathrm{N}$} & \multicolumn{4}{|c|}{ ANOVA } & \multirow{2}{*}{$\mathrm{F}$} & \multirow{2}{*}{$\begin{array}{l}\text { post } \\
\text { hoc }\end{array}$} \\
\hline & & & Source & SS & Df & MS & & \\
\hline \multirow{3}{*}{ Cost } & 1.primary school & 125 & Inter & 1577124 & 2 & 788562 & 12.2 & $3>1$ \\
\hline & 2.Middle school & 48 & Intra & 13311233 & 206 & 64617 & & $3>2$ \\
\hline & 3.High school & 36 & Agg. & 14888357 & 208 & & & \\
\hline \multirow{3}{*}{$\begin{array}{l}\text { Quality } \\
\text { generate cost } \\
\text { differ. }\end{array}$} & 1.primary school & 125 & Inter & 5147617 & 2 & 2573808 & 25.3 & $3>1$ \\
\hline & 2.Middle school & 48 & Intra & 20967746 & 206 & 101785 & & $3>2$ \\
\hline & 3.High school & 36 & Agg. & 26115364 & 208 & & & \\
\hline
\end{tabular}


Table 3. AHP results

\begin{tabular}{|c|c|c|c|c|c|}
\hline \multicolumn{2}{|c|}{ Dimension } & \multicolumn{2}{|c|}{ Aspect } & \multicolumn{2}{|l|}{ Factor } \\
\hline \multirow{4}{*}{ Learning } & \multirow{4}{*}{0.43} & \multirow{2}{*}{ Academics } & \multirow{2}{*}{0.60} & Curriculum design & 0.35 \\
\hline & & & & Teacher quality & 0.65 \\
\hline & & \multirow{2}{*}{ Environment } & \multirow{2}{*}{0.40} & School location & 0.58 \\
\hline & & & & Research facilities & 0.42 \\
\hline \multirow{4}{*}{ Economics } & \multirow{4}{*}{0.57} & \multirow[b]{2}{*}{ Strategy } & \multirow[b]{2}{*}{0.44} & Admission criteria & 0.45 \\
\hline & & & & $\begin{array}{l}\text { Graduation } \\
\text { requirements }\end{array}$ & 0.55 \\
\hline & & \multirow{2}{*}{ Benefits } & \multirow{2}{*}{0.56} & Work benefit & 0.62 \\
\hline & & & & Promotion potential & 0.38 \\
\hline
\end{tabular}

Table 4. Price differentials for school selection factors

\begin{tabular}{|c|c|c|c|c|c|c|c|c|}
\hline & $\begin{array}{c}\text { Curriculum } \\
\text { design }\end{array}$ & $\begin{array}{c}\text { Teacher } \\
\text { quality }\end{array}$ & $\begin{array}{c}\text { School } \\
\text { location }\end{array}$ & $\begin{array}{c}\text { Research } \\
\text { facilities }\end{array}$ & $\begin{array}{c}\text { Admission } \\
\text { criteria }\end{array}$ & $\begin{array}{c}\text { Graduation } \\
\text { requirements }\end{array}$ & $\begin{array}{c}\text { Work } \\
\text { benefit }\end{array}$ & $\begin{array}{c}\text { Promotion } \\
\text { potential }\end{array}$ \\
\hline $\begin{array}{c}\text { Weighting } \\
\text { (W) }\end{array}$ & 0.091 & 0.167 & 0.099 & 0.073 & 0.111 & 0.137 & 0.199 & 0.122 \\
\hline $\begin{array}{c}\text { Weighted } \\
\text { price } \\
\text { differential }\end{array}$ & 14.4 & 26.5 & 15.6 & 11.5 & 17.6 & 21.7 & 31.5 & 19.4 \\
\hline
\end{tabular}

Table 5. Comparative Strengths of the competing universities

\begin{tabular}{|c|c|c|c|c|}
\hline Factors & UA & UB & UC & UD \\
\hline Curriculum design & 3.61 & 3.81 & 3.02 & 3.37 \\
\hline Teacher quality & 3.63 & 3.93 & 3.00 & 3.38 \\
\hline School location & 3.73 & 3.39 & 2.69 & 3.11 \\
\hline Research facilities & 3.44 & 3.93 & 3.02 & 3.39 \\
\hline Admission criteria & 3.38 & 3.42 & 3.19 & 3.24 \\
\hline Graduation requirements & 3.26 & 3.29 & 3.33 & 3.21 \\
\hline Work benefit & 3.59 & 3.76 & 3.06 & 3.34 \\
\hline Promotion potential & 3.52 & 3.64 & 3.12 & 3.44 \\
\hline
\end{tabular}

Table 6. Relative tuition rate of the competing universities

\begin{tabular}{|c|c|c|c|c|c|}
\hline Universities & UA & UB & UC & UD & $\begin{array}{c}\text { Average of all } \\
\text { competitors }\end{array}$ \\
\hline UA (913) & NA & 1,646 & 1,765 & 1,316 & 1,576 \\
\hline UB $(1,666)$ & 933 & NA & 1,785 & 1,336 & 1,351 \\
\hline UC $(1,692)$ & 840 & 1,573 & NA & 1,244 & 1,219 \\
\hline UD $(1,283)$ & 880 & 1,613 & 1,731 & NA & 1,408 \\
\hline
\end{tabular}




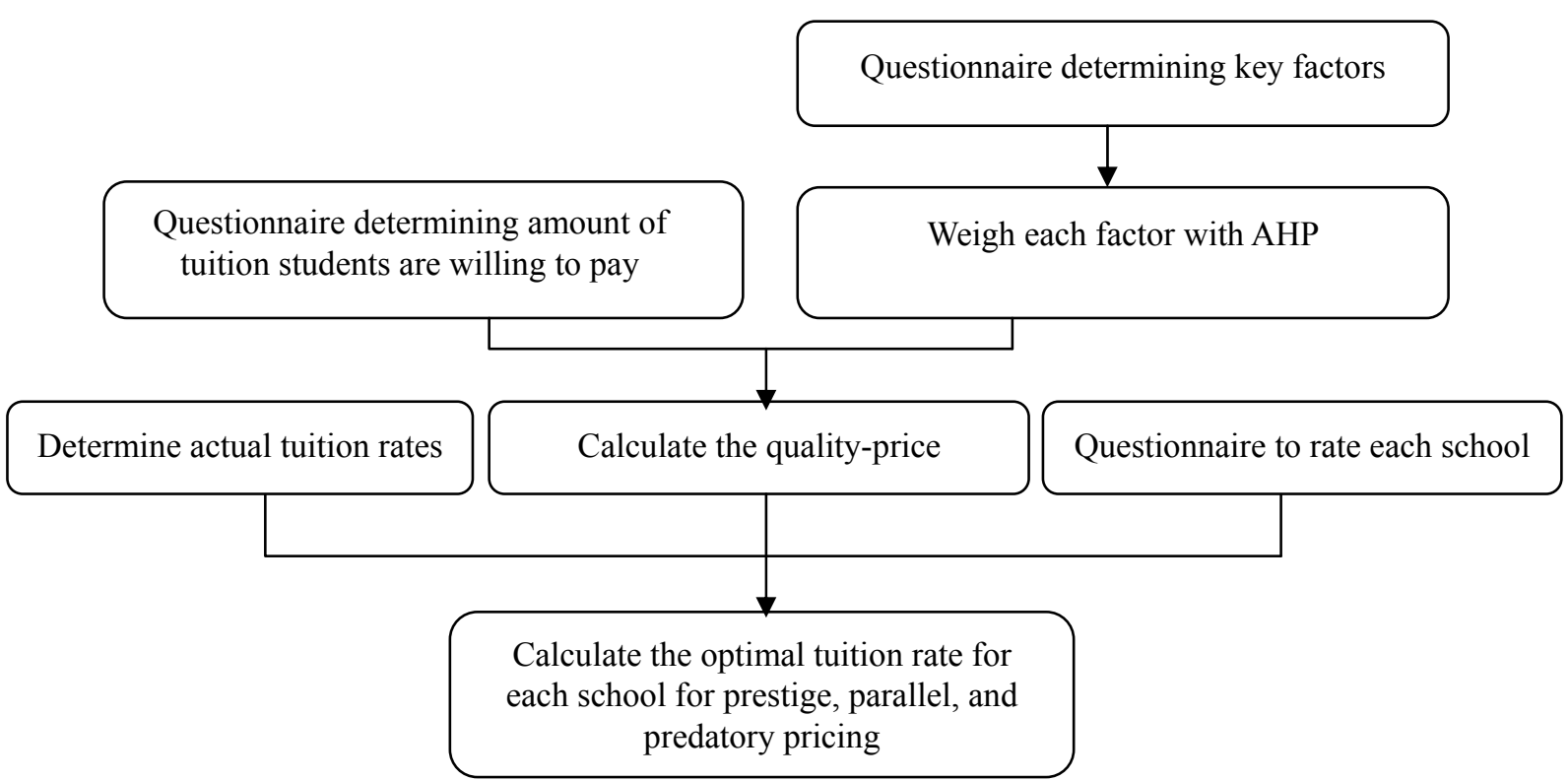

Figure 1. Research Structure

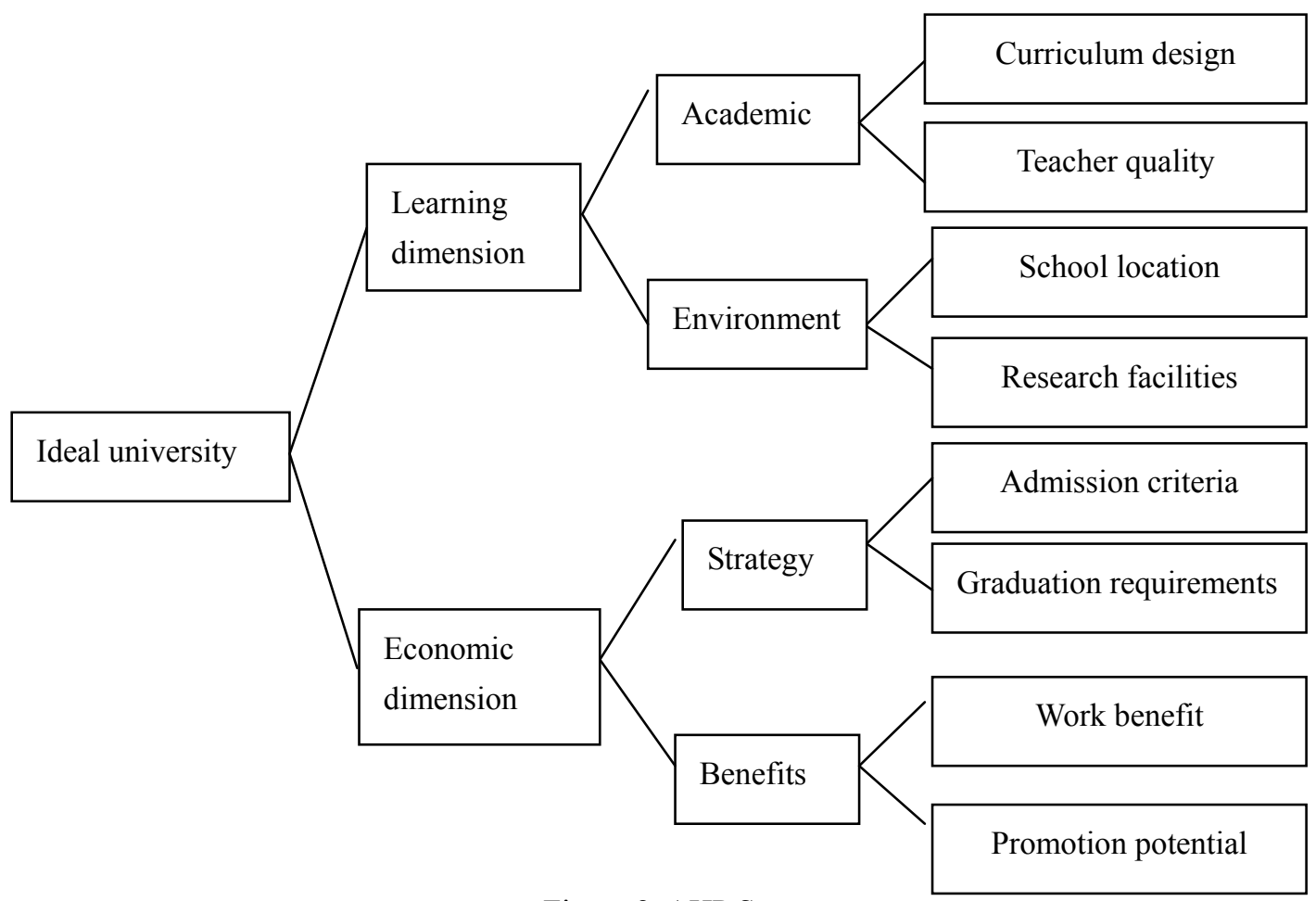

Figure 2. AHP Structure 


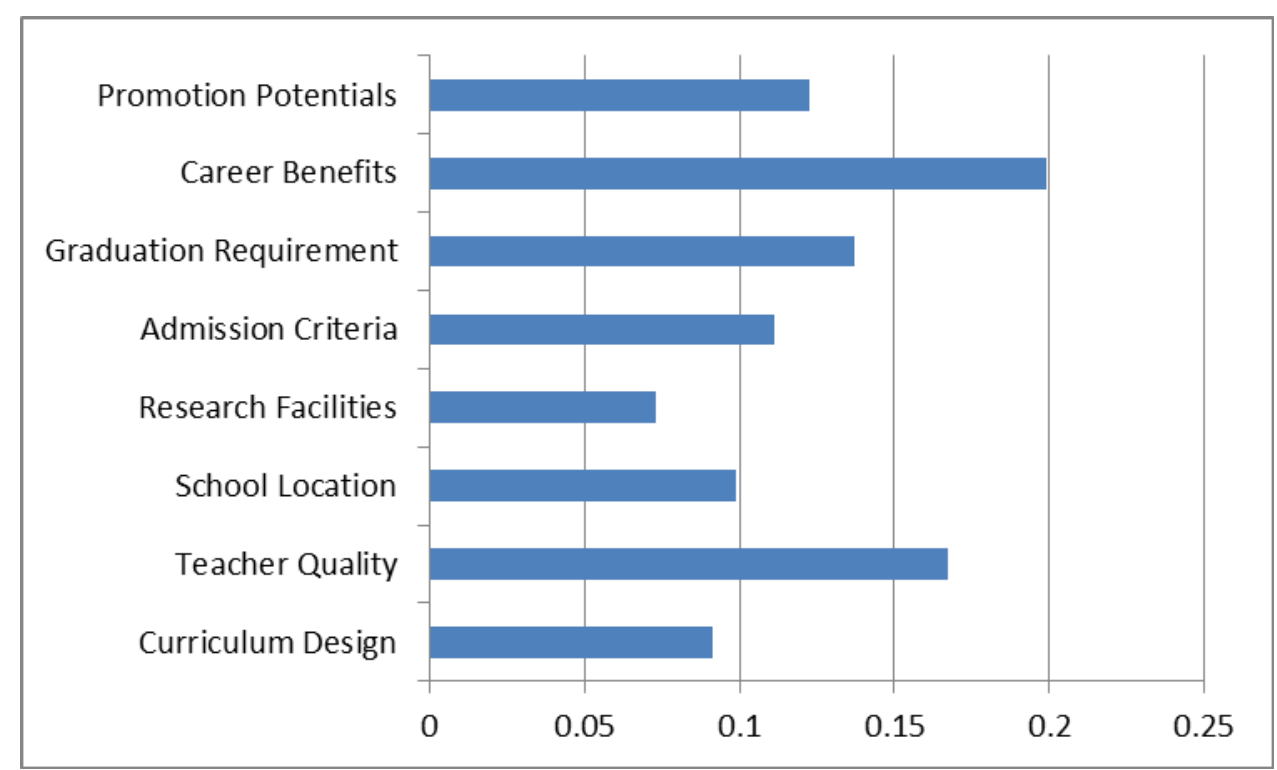

Figure 3. Comparative weighting of school selection factors 